\begin{tabular}{|c|c|}
\hline \multirow{3}{*}{ 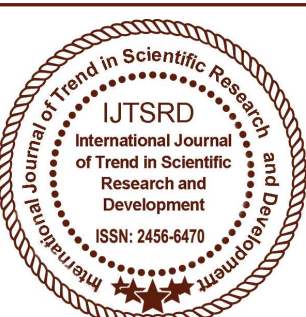 } & $\begin{array}{l}\text { International Journal of Trend in Scientific } \\
\text { Research and Development (IJTSRD) }\end{array}$ \\
\hline & International Open Access Journal \\
\hline & ISSN No: $2456-6470$ | www.ijtsrd.com | Volume - 2 | Issue -3 \\
\hline
\end{tabular}

\title{
A Study on road accidents and detection of driver's distraction
}

\author{
${ }^{1}$ Mrs Deepalakshmi. G, ${ }^{2}$ Mr. S. Ajith Kumar, ${ }^{3}$ Mr. K. Anand, ${ }^{4}$ Mr. S. Ashok, ${ }^{5}$ Mr. S. SasiKumar \\ ${ }^{1}$ Assistant Professor, ${ }^{2,3,4,5}$ Student \\ 1,2,3,4,5 Department of IT \& CT, VLB Janakiammal College of Arts Science, \\ Kovaipudur, Coimbatore, Tamil Nadu, India
}

\begin{abstract}
The number and quantity of vehicles on roads have enlarged due to technological and cost-effective progress in recent years. As a result of this increase, Avoiding the traffic and accidents have become one of the most important parts of our daily lives as people spend more time in traffic thereby forcing drivers and other road users to face a higher risk of the traffic accident. Road accidents are an outcome of the interplay of various factors, some of which is a length of the road network, vehicle population, human population and enforcement of road safety regulations.

The number one cause of car accidents is not a criminal that drove drunken, speed or ran a red light. Distracted drivers are the top cause of car accidents in most of the countries. A distracted driver diverts his or her attention from the road, usually to talk on a cell phone, send a text message or eat food. This study has discussed the statistics of road accidents and the top ten states in India's accidental death rates, common behavior of drivers which causes the accidents and distraction types. This paper proposed a methodology of detecting the distraction of drivers by calculating the heartbeat rate of the drivers when he or she is distracted.
\end{abstract}

\section{INTRODUCTION:}

Every year road accidents claim the lives of 1.3 million people worldwide. Every hour, 40 people under the age of 25 die in road accidents around the globe. Between 20 and 50 million more people suffer non-fatal injuries, with many incurring a disability as a result of their injury. Road traffic injuries cause considerable economic losses to individuals, their families, and to nations as a whole. These losses arise from the cost of treatment as well as lost productivity for those killed or disabled by their injuries, and for family members who need to take time off work or school to care for the injured. Automobile-related deaths in developing countries, with young people in the age groups from 5 to 24 years old possessing the highest risks

Over 1, 37,000 people were killed in road accidents in 2013 alone, that is more than the number of people killed in all our wars put together. 16 children die on Indian roads daily. 5 lives end on Delhi's roads every day. There is one death every four minutes due to a road accident in India. One serious road accident in the country occurs every minute and 16 dies on Indian roads every hour. India witnessed 17 deaths and 55 road accidents every hour in 2016, one of the highest in the world, according to the latest report released by the Union road transport and highways ministry.

The report compiled by the ministry's Transport Research Wing said road accidents killed 150,785 people across India in 2016 - a 3.3\% jump from 2015 when 146,000 larks road fatalities were reported - indicating Indian roads continue to be one of the deadliest in the world. The number of road accidents, however, declined from 501,000 lakh in 2015 to 480,652 lakh in 2016. 
India recorded at least 4, 80,652 accidents in 2016, leading to $1,50,785$ deaths. The number suggests that at least 413 people died every day in 1,317 road accidents. Further breaking down the statistics, the data reveals that at least 17 deaths occurred in road accidents in 55 accidents every hour in the given time period. Comparing the new recordings with data from previous year shows that in spite of recording fewer accidents in 2016, more deaths have occurred this year as in 2015 . In $2015,1,46,133$ people had died in $5,01,423$ accidents. The accident severity, which is measured as the number of persons killed per 100 accidents, was recorded at 29.1 in 2015 which is lower than 31.4 in 2016.

\section{ROAD ACCIDENT:}

A Road accident refers to an accident involving at least one road open to public circulation and in which at least one person is injured or killed Intentional acts (murder, suicide) and natural disasters are excluded.

Road accident is the most unwanted thing to happen to a road user, though they happen fairly often. The most regrettable thing is that we don't learn from our mistakes on road. Most of the road users are quite well aware of the general rules and safety measures while using roads but it is only the laxity on part of road users, which cause accidents and crashes. The main cause of accidents and crashes are due to human errors.

Traffic accident is major cause of death and injuries worldwide but while they are declining in many parts of the developed world fatalities are still on the rise in many developing countries including India In our Tamilnadu state more than haunts of the road accident victims are in the group of 20 to 55, the key wage earning and child raising age group.

The common behavior of humans which results in accident.

1. Over Speeding

2. Drunken Driving

3. Distractions to Drive

4. Red Light Jumping

5. Avoiding Safety Gears like Seat belts and Helmets

6. Non-adherence to lane driving and overtaking in a wrong manner

\begin{tabular}{|l|l|l|l|l|l|l|}
\hline \multirow{2}{*}{ Top Ten States } & \multicolumn{9}{|c|}{ Injuries } & \multicolumn{2}{l|}{ Fatalities } \\
\cline { 2 - 8 } & ADSI & TRW & ADSI & TRW & ADSI & TRW \\
\hline Uttar Pradesh & 28095 & 32385 & 17384 & 23205 & 18407 & 17666 \\
\hline Tamil Nadu & 69059 & 69059 & 79746 & 79746 & 15642 & 15642 \\
\hline Maharashtra & 42250 & 63805 & 39301 & 39606 & 13685 & 13212 \\
\hline Karnataka & 44011 & 44011 & 56971 & 56971 & 10857 & 10856 \\
\hline Rajasthan & 24072 & 24072 & 26153 & 26153 & 10510 & 10510 \\
\hline Madhya Pradesh & 40859 & 54947 & 40878 & 55815 & 9758 & 9314 \\
\hline Andhra Pradesh & 22839 & 24258 & 29439 & 29439 & 8297 & 8297 \\
\hline Gujarat & 23362 & 23183 & 21505 & 21448 & 8245 & 8119 \\
\hline Telangana & 21252 & 21252 & 22948 & 22948 & 7110 & 7110 \\
\hline West Bengal & 17706 & 13208 & 15504 & 11794 & 6705 & 6234 \\
\hline Total (All India) & $\mathbf{4 6 4 6 7 4}$ & $\mathbf{5 0 1 4 2 3}$ & $\mathbf{4 8 2 3 8 9}$ & $\mathbf{5 0 0 2 7 9}$ & $\mathbf{1 4 8 7 0 7}$ & $\mathbf{1 4 6 1 3 3}$ \\
\hline
\end{tabular}

Road crash cases in top 5 Indian States between years 2013 and 2016

\begin{tabular}{|l|l|l|l|l|}
\hline States & $\mathbf{2 0 1 3}$ & $\mathbf{2 0 1 4}$ & $\mathbf{2 0 1 5}$ & $\mathbf{2 0 1 6}$ \\
\hline Tamilnadu & 66538 & 67250 & 69059 & 71025 \\
\hline Karnataka & 39591 & 43694 & 44011 & 45921 \\
\hline Maharashtra & 43863 & 44382 & 42250 & 40998 \\
\hline Uttar Pradesh & 25975 & 26064 & 28095 & 30542 \\
\hline Rajasthan & 23586 & 24639 & 24072 & 23958 \\
\hline
\end{tabular}

\section{Accident Details in Tamil Nadu for Certain Years State : Tamil Nadu}

\begin{tabular}{|c|l|l|l|l|l|l|l|l|c|}
\hline \multirow{2}{*}{ YEAR } & \multicolumn{3}{|c|}{ FATAL } & $\begin{array}{l}\text { Grievous } \\
\text { Injury }\end{array}$ & & $\begin{array}{l}\text { Minor } \\
\text { Injury }\end{array}$ & $\begin{array}{l}\text { Non- } \\
\text { Injury }\end{array}$ & $\begin{array}{l}\text { Total } \\
\text { Accidents }\end{array}$ & $\begin{array}{c}\text { Total } \\
\text { Number } \\
\text { of } \\
\text { Persons } \\
\text { involved }\end{array}$ \\
\cline { 2 - 10 } & N.A & N.P.k & N.A & N.P.I & N.A & N.P.I & N.A & & \\
\hline 2010 & 14241 & 15409 & 4613 & 6844 & 42320 & 68601 & 3822 & 64996 & 90854 \\
\hline 2011 & 14359 & 15422 & 4619 & 6573 & 42766 & 67672 & 4129 & 65873 & 89667 \\
\hline 2012 & 15072 & 16175 & 4851 & 6972 & 44604 & 71376 & 3230 & 67757 & 94523 \\
\hline 2013 & 14504 & 15563 & 4715 & 6513 & 44158 & 69168 & 2861 & 66238 & 91244 \\
\hline 2014 & 14165 & 15190 & 5375 & 7381 & 45100 & 70344 & 2610 & 67250 & 92915 \\
\hline 2015 & 14524 & 15642 & 7388 & 9400 & 44880 & 70301 & 2267 & 67250 & 95343 \\
\hline 2016 & 16092 & 17218 & 6262 & 8421 & 46908 & 73742 & 2169 & 71431 & 99381 \\
\hline
\end{tabular}




\section{Types of Accident:}

The following are the five most common Types of Car accidents and advice on how to best avoid them.

1. Rear-end Collision

2. Single vehicle crashes

3. T-bone or cross-Traffic accident

4. Clipping other cars when merging.

5. Low-speed accidents.

According to the national floor safety Institution (NFSI), slip and fall accident are the leading cause of workers compensation claims. Some of the most common types of injuries suffered in slip and fall accidents include fractured, Sprains knee injuries and hand or wrist injuries.

\section{DISTRACTIONS:}

Driver distraction is an important risk factor for road traffic injuries. There are different types of driver's distraction, usually divided into those where the source of distraction is internal to the vehicle such as tuning a radio or using a mobile phone and those external to the vehicle such as looking at billboards or watching peoples on the side of the road.

\section{Visual:}

Looking away from the road for a non-during related task.

\section{Cognitive:}

Reflecting on a subject of conversation as a result of following on the Phone-rather road situation.

\section{Physical:}

When the driver holds or with both hands or dialing or a mobile phone or operates a device rather than sleeping with both hands or dialing on a mobile or learning over tune a radio that may lead to rotating the steering wheel.

\section{Auditory:}

Responding to a ringing mobile or if a devices is turned is so loud that it mark other sounds such as ambulance sirens

\section{Objectives of the proposed system}

1. To detect the distraction of drivers and to avoid road crashes.
2. Using Face Detector Sensor and Heart Beat Reader to measure the deviations of Drivers

\section{Methodologies:}

In order to design safe vehicles, it is important to be able to evaluate in-vehicle systems to determine how distracting they are for people to use while driving. The Peripheral Detection Task (PDT) is a method for measuring the amount of driver mental workload and visual distraction in road vehicles. It is a secondary task measure where drivers must respond to random

Targets presented in their peripheral view. As drivers become distracted they respond slower and miss more of the PDT targets. This study aimed to test if the PDT is useful for measuring driver mental workload and visual distraction from in-vehicle information systems in the real road traffic environment.

\section{HOW TO CONTROL: Heart Beat Rate}

When the heart beats, a pressure wave moves out along the arteries at a few meters per seconds (appreciably faster than the blood actually flows). This pressure wave can be felt at the wrist, but it also causes an increase in the blood volume in the tissues, which can be detected.

The following Table shows the average heartbeat rate range versus the age of the person.

\begin{tabular}{|l|l|l|}
\hline AGE & RANGE & AVERAGE RATE \\
\hline $0-1$ Month & $100-180$ & 140 \\
\hline $2-3$ Month & $110-180$ & 145 \\
\hline $4-12$ Month & $80-180$ & 130 \\
\hline 1- 3 years & $80-160$ & 120 \\
\hline 4-5 years & $80-120$ & 100 \\
\hline 6-8 years & $70-115$ & 92.5 \\
\hline $9-11$ Years & $60-110$ & 85 \\
\hline $12-16$ years & $60-110$ & 85 \\
\hline$>16$ Years & $60-100$ & 80 \\
\hline
\end{tabular}

\section{Average heartbeat rate range versus the age of a person}

Normal Heart Beat rate differs. There is no single number constantly. Heartbeat rate differs based on age, sex, weight, physical condition and other factors.

The following table shows the different situation or person's Heart Rate. 


\begin{tabular}{|l|l|l|}
\hline S.No & Category & Heart Rate in bpm (beats per minute) \\
\hline 1 & Adults & $60-100 \mathrm{bpm}$ \\
\hline 2 & Athlete's & $40 \mathrm{bpm}$ (good physic for them) \\
\hline 3 & $\begin{array}{l}\text { Jumping from airplane, watching a } \\
\text { horror film }\end{array}$ & $170 \mathrm{bpm}$ \\
\hline 4 & Drivers & $181 \mathrm{bpm}$ (maximum ) \\
\cline { 3 - 3 } & & $153($ average) \\
\hline 5 & Rollercoaster ride & $155 \mathrm{bpm}$ \\
\hline 6 & Proposing a girl friend & $130 \mathrm{bpm}$ \\
\hline
\end{tabular}

\section{Heart rate of various situation or person}

\section{EQUIPMENT:}

The PDT presents a small red target light on the windscreen in the driver's perifoveal field of view. The target is an LED reflection on the windscreen. The reflections appear as a heads-up display (HUD). The HUD target is located at a horizontal angle of approximately 11- 23 degrees to the left of the driver's forward view and at a vertical angle of approximately 2-4 Degrees above the horizon. The target appears within this area; one of 23 LEDs in the rack is illuminated. The targets appear with a random variation between 3-6 seconds. It lasts for one second and the response is possible from 200 milliseconds after onset until 2 seconds, otherwise it is considered a miss. Drivers respond to the targets by pressing a small button attached to their left index finger.

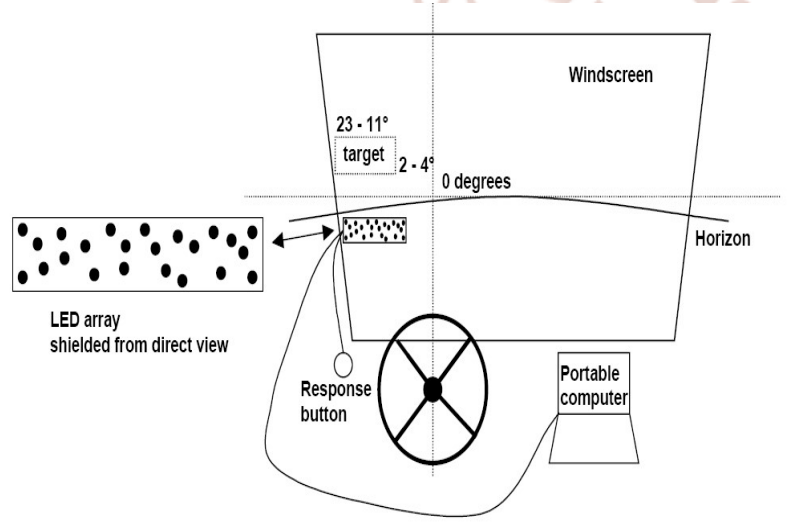

The Peripheral Detection Task Hardware

The electrocardiograph (ECG) signals were taken with an ambulatory monitoring device The $0.1 \mathrm{~Hz}$ component of heart rate variability (HRV) was obtained using the analysis software Somnologica. The $0.1 \mathrm{~Hz}$ component of HRV was extracted since it has been associated with the mental effort Less variability or lower values of this measure indicate more mental effort. The Rating Scale Mental Effort (RSME) was used to rate subjective workload. This is a single scale that consists of a line that runs from $0-150 \mathrm{~mm}$, where every $10-\mathrm{mm}$ is marked. Along this line statements related to the invested effort are given Procedure.

The participants will be first given the test instructions and the PDT was explained. After this, the ECG equipment will be connected. This was followed by a 5-minute rest period to collect baseline data for the ECG. The participants will be instructed where to drive. The test vehicle will be given. The road trial started with a familiarization/practice drive. The next part will be on a motorway and the last part will be on a 2-lane undivided road with a number of traffic lights. Participants are instructed to perform the tasks at set points along the route. An unbalanced repeated measures design was used. The independent variables like road type/speed, motorway $(110 \mathrm{~km} / \mathrm{h})$ and country road $(90 \mathrm{~km} / \mathrm{h})$ and task, embedded or cognitive will be declared.

The embedded tasks will be determined

1. the tuned frequency on the radio and manually select a specific radio station (Task 1, Radio),

2. The cognitive task used was a backward counting task, for example, 568-7 (Task 2, Counting).

3. Turn on the CD-player and play a specific track on a specific $\mathrm{CD}$, for example, track 3 on $\mathrm{CD} 1$ (Task 3, CD). 
The dependent measures will be heart rate variability, subjective mental effort, PDT reaction time and target hit rate. The HRV and PDT performance were recorded throughout the drive. The RSME was completed after each road section. PDT performance was summarized over 30 -second intervals surrounding the tasks. The baseline performance was recorded over a 5-minute period so that a sufficient amount of data could be collected to calculate the power of the mental workload component of the HRV.

\section{CONCLUSION:}

The papers provide the study on road accidents and their statistics are highlighted based on the different type of road accidents and various factors. This paper also studied about the distraction of drivers and how to control the distraction rate. Driver's heart rate is calculated and the alarm will alert when the distraction is detection on drivers. The proposed system helps to detect the distraction in which the road accidents can be controlled and can also be reduced when it is implemented.

\section{REFERENCE:}

1. M. J Drinnan, J. Allen, and A. Murray (2001). "Relation between heart rate and pulse transit time during paced respiration", Physiol. Meas. vol. 22, pp425-432.

2. A.S. Knapper, M.P. Hagenzieker, K.A. Brookhuis, Do in-car devices affect experienced Users\&\#39; driving performance? IATSS Res. 39 (2015) 72 78

3. D.B. Kaber, Y. Liang, Y. Zhang, M.L. Rogers, S. Gangakhedkar, Driver performance effects of simultaneous visual and cognitive distraction and adaptation behaviour, Transport. Res. F: Traffic Psychol. Behav. 15 (5) (2012) 491-501.

4. K.L. Young, M.G. Lenné, Driver engagement in distracting activities and the strategies used to minimise risk, Saf. Sci. 48 (3) (2010) 326-332.

5. Mohan, D., M. Khayesi, F.M. Nafukho and G. Tiwari (eds) (2006) \&\#39;Road Traffic Injury Prevention-Training Manual\&\#39; WHO and Indian Institute of Technology Delhi

6. Expert committee on auto fuel policy. Urban road traffic and air pollution in major Cities Volume 1: pp.1-395.New Delhi
7. Government of India. (2002).CRRI. Annual Report 2007. New Delhi, Central Road Research Institute. (2007).

8. Kumar, R.P., Venkatramayya, V., \&amp; Kashinath, T. Macro level study of road accidents on Dindigul-Palani section of NH-209. "Indian High-ways" 32: pp.31-38. (2004).

9. Global status report on road safety 2015\&quot;,World Health Organization, 2016. [Online].Available:http://www.who.int/violence_i njury_prevention/road safety status/en/.

10. V. Goud, \&quot;Vehicle Accident Automatic Detection and Remote Alarm Device\&quot; International Journal of Reconfigurable and Embedded Systems (IJRES), Vol.1.no 2. 2012

11. Mohd Fadzly Othman (2006). "Developing a Heartbeat Monitoring System Using PI Microcontroller". KUiTTHO: Thesis B. Eng.

12. Cropper, M.L. \& Kopits, E. Traffic Fatalities and Economic Growth."World Bank Policy Research Working Paper" 3035: pp.1-42. Washington D.C., World Bank. (2003).

13. Ramya Keerthi, G.Shanmukh, Dr. R.Sivaram, Various Accident Detection Technologies and Recovery Systems - withVictim Analysis, International Journal of Advanced Trends in Computer Scienceand Engineering (IJATCSE), Vol.2 , No. pp: 07-12, Special Issue of ICCSIE 2013.

14. P. Dhole, S. Shaikh, N. Gite and V.Sonawane, \&quot;Smart Accident Detection \&amp; of Emerging Trends in Science and Technology, Vol. 2, no. 4, pp. 2285-2288, 2015.

15. Saija, K.K. \&amp; Patel, C.D. Micro level study of accidents on NH-8 passing through Valsad District. "Indian Highways" 30: pp.43-51. (2002).

16. Shrinivas, P.L.L. Studies undertaken to identify critical causes of accidents in the highways of Tamil Nadu. "Indian Highways" 31: pp.11-22. (2004) 